\title{
Law and Narrative in the Bible and in Neighbouring Ancient Cultures
}

\author{
Ed. by Klaus-Peter Adam, Friedrich Avemarie and Nili Wazana, co-ed. by Dorit
} Felsch

[Recht und Erzählung in der Bibel und benachbarten antiken Kulturen.]

Law and Narrative in the Bible and in Neighbouring Ancient Cultures Edited by KLAUS-PETER ADAM, FRIEDRICH AVEMARIE and NILI WAZANA

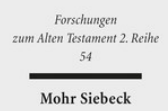

2012. XVII, 414 Seiten. FAT II 54

ISBN 978-3-16-152123-2

DOI 10.1628/978-3-16-152123-2

eBook PDF 99,00€

ISBN 978-3-16-150843-1

fadengeheftete Broschur 99,00€
Veröffentlicht auf Englisch.

Recht ist nicht nur Gegenstand von Rechtssätzen, sondern ist oft auch zentraler Gegenstand literarischer Texte: Bestehende Rechtsverhältnisse können den historischen oder fiktiven Rahmen eines Dramas oder einer Erzählhandlung bestimmen. Erzählungen können darauf abzielen, Rechtsnormen einzuführen, zu propagieren, zu problematisieren oder gar anzuprangern und sie sind konstitutiver Bestandteil von Strategien zur Durchsetzung konkreter rechtlich begründeter Forderungen. Die Autoren der Beiträge des vorliegenden Bandes wählen aus den Feldern des Verfassungs- und Verwaltungsrechts, des Verfahrensrechts, des Familien- und Erbrechts, sowie Eigentum, Schadensersatz, Strafe, Privilegierung, Versorgung. Sie untersuchen literarische Texte und Gebrauchstexte aus der Bibel, dem alten Orient, dem frühen Judentum und der klassischen Antike.

Inhaltsübersicht

Cornelia Wunsch : Legal Narrative in the Neo-Babylonian Trial Documents: Text Reconstruction, Interpretation, and Assyriological Method - Wolfgang Oswald: Die Exodus-Gottesberg-Erzählung als Gründungsurkunde der judäischen Bürgergemeinde - Udo Rüterswörden: Gesetz und Erzählung anhand der Josephsgeschichte - Nili Wazana: »For an Impaled Body is a Curse of God« (Deut 21:23): Impaled Bodies in Biblical Law and Conquest Narratives - Klaus-Peter Adam: A Didactic Case Narrative on Homicide Law: 1 Samuel 26 - Rache/ Magdalene : The Reader as Judge in the Book of Job: Interpretation and the Narrativity of Case Law - Joachim Hengstl: Rechtliche Anliegen in biblischen Schilderungen. Methodische Gesichtspunkte - Susanne Gödde: Recht ohne Gesetz? Szenarien der Rechtssprechung bei Homer, Hesiod und Aischylos - Stefan Krauter: Rechtsnorm und Beispielerzählung im Dienste der Überzeugung. M. Tullius Cicero, De domo sua ad pontifices - Beate Ego: "Diejenigen, welche die Wahrheit tun, werden Gelingen haben in ihren Werken« (Tob 4,6). »Law« und »narrative« im Buch Tobit - Cana Werman: Narrative in the Service of Halakha: Abraham, Prince Mastema, and the Paschal Offering in Jubilees Lutz Doering: Reinheit und Tempel. Ein Beitrag zum Verhältnis von Law und Narrative im Jubiläenbuch - Tal Ilan: Babatha the Killer-Wife: Literature, Folk Religion and Documentary Papyri - Catherine Hezser: Orality, Textuality, and Memory in the Transmission of Rabbinic Legal Narratives - Lukas Bormann: Das Lukasevangelium als tragische Geschichtserzählung vom Zusammenbruch der Rechtsgemeinschaft des Judentums in Galiläa und Judäa - Douglas A. Hume : "Sharing All Things in Common«: Narrative, Alienation, and the Friendship Ethos in Acts 2:41-47 and 4:32-35 - Eyal Regev : The Gradual Conversion of Gentiles in Acts and Luke's Paradox of the Gentile Mission - Friedrich Avemarie: The Apostolic Decree and the Jewishness of Luke's Paul: On the Narrative Function of Acts 15:23-29

Klaus-Peter Adam Born 1965; studied Protestant Theology in Berlin, Tübingen, München; 1999 PhD; 2005 Habilitation; Professor of Old Testament at the Lutheran School of Theology at Chicago.

Friedrich Avemarie (1960-2012) Studium der Ev. Theologie in Heidelberg, München, Montpellier und Tübingen; Studium der Judaistik in Jerusalem und Berlin; 1995 Promotion; 2000 Habilitation; 2002-12 Professor für Neues Testament und antikes Judentum in Marburg.

Dorit Felsch Geboren 1979; Studium der Evangelischen Theologie in Tübingen und Leipzig; 2010 Promotion; Vikarin der Evangelischen Kirche im Rheinland in Wuppertal.

Nili Wazana Born 1962; Senior Lecturer in the Departments of Bible and History of the Jewish People and Contemporary Judaism at the Hebrew University, Jerusalem, Israel.

Jetzt bestellen:

https://mohrsiebeck.com/buch/law-and-narrative-in-the-bible-and-in-neighbouring-ancient-cultures-9783161521232? no_cache=1

order@mohrsiebeck.com

Telefon: +49 (0)7071-923-17

Telefax: +49 (0)7071-51104 